\title{
The Intersection between Film and Opera in the 1960s: Ingmar Bergman's Hour of the Wolf as an Example of Formal Imitation
}

Johanna Ethnersson Pontara

\begin{abstract}
The topic of this article is the intersection between media genres in I960s Sweden. In a case study of Ingmar Bergman's Hour of the Wolf (I968) it is shown how the music contributes to intermedial qualities through the film's connection with opera. It is argued that the film, by how the music is related to sound effects and images, can be seen as an example of formal imitation. The imitation of opera is created through technical media of film, such as foregrounding of media in the audio-visual space, and manipulations of sounds, music, and images. Of special interest is how, by alternating between synchronicity and counterpoint between images, sound effects, and music, Bergman attracts attention to the media as visual and sonic experiences and creates formal structures that deviate from the overall character of the film. The intermedial dimension of the film revealed by the analysis is contextualized in relation to the historical discussion of mixed versus pure medialities. The film is seen in the light of an interest in media genre mixedness versus media genre specificity in I960s Sweden.
\end{abstract}

\section{Introduction}

In a review of Ingmar Bergman's Hour of the Wolf (Vargtimmen, I968) published in the American film journal Film Quarterly

How to cite this book chapter:

Ethnersson Pontara, Johanna. "The Intersection between Film and Opera in the I960s: Ingmar Bergman's Hour of the Wolf as an Example of Formal Imitation." In The Power of the In-Between: Intermediality as a Tool for Aesthetic Analysis and Critical Reflection, edited by Sonya Petersson, Christer Johansson, Magdalena Holdar, and Sara Callahan, 49-74. Stockholm: Stockholm University Press, 20I8. DOI: https://doi.org/Io.I6993/baq.c. License: CC-BY. 
in the summer I968, film critics Richard Corliss and Jonathan Hoops posited that the film drew upon an operatic mode. The critics took into consideration how the film alluded to W. A. Mozart's The Magic Flute (Die Zauberflöte, I79I); however, they also characterized the film as "frankly operatic," and described how it pointed to opera through structural devices:

In Hour of the Wolf, the model is Mozart's The Magic Flute and, though a specific reference to it during the party seems at first superfluous, we later realize that it is doubly relevant: because the film is a retelling of the Magic Flute story, and because, whereas the dramas from Through a Glass Darkly to Persona were "chamber" films (described by Jörn Donner as covering "short spans of time with few actors" and possessing "something of the character of intimate music"), Hour of the Wolf is frankly operatic. The settings are expansive rather than constrictive; there are many characters, and each is given a verbal aria; the treatment, like most libretti, is melodramatic in the extreme. The film draws its inspiration from The Magic Flute's artful conglomeration of magic, music, farce, and fragmentary statements of high-sounding philosophy. ${ }^{\mathrm{I}}$

Corliss and Hoops' description of the film focused on visual and verbal media: the configuration of the settings, the number of characters, and how the characters appeared verbally. Then, which intermedial qualities can be revealed through the film's connection with opera? Moreover, how does the music, a central medium of the film as well as of opera as a media genre, contribute to such qualities?

The film genre's relationship with opera, one of its precursors, is an issue that has attracted attention among scholars during the last decades. ${ }^{2}$ The interest in combining traits from the two media genres in innovative productions was strong in the I920s and I930s (examples of this are Alban Berg's Lulu and the screen

I Richard Corliss and Jonathan Hoops, "Hour of the Wolf," review of Hour of the Wolf, by Ingmar Bergman, Film Quaterly 2I:4 (I968): 38, accessed October 29, 20I 5, http:/Www.jstor.org/stable/I 2 I0600? seq= I\#page_scan_tab_contents.

2 Cf. Joe Jeongwon and Rose Theresa, eds., Between Opera and Cinema (New York: Routledge, 2002); Marcia Citron, When Opera Meets Film (Cambridge: Cambridge University Press, 2010). 
version of Richard Strauss' The Cavalier of the Rose). Recently, however, scholars have also paid attention to how film and opera intersect in multimedia products from the I960s, a period of time when genre-specific traits were called into question. It has been shown how composers and directors drew on experiences with cinema and television in attempts to reinvigorate the opera genre, ${ }^{3}$ and how European art film directors created spectacular and distancing effects by drawing on aesthetics of opera. ${ }^{4}$

The film production of Bergman from the I960s provides interesting objects of investigation in this context. Just like contemporary art film directors such as Andrei Tarkovsky (I932-86) and Jean-Luc Godard (born I930), Bergman often challenges a traditional narrative cinematic discourse, and an important means by which this is achieved is the music. ${ }^{5}$ Per F. Broman has shown how an important characteristic of Bergman's use of music is to let it dominate the narrative to the extent that the domains of diegetic and extra diegetic is blurred. ${ }^{6}$ Furthermore, it has been shown how Bergman reveals an awareness of the film viewer through the way in which he combines images and sounds. Alexis

3 Cf. Harriet Boyd, "Remaking Reality: Echoes, Noise and Modernist Realism in Luigi Nono's Intolleranza I 960," Cambridge Opera Journal 24:2 (2012): I77-200; Andrea Santini, "Multiplicity - Fragmentation Simultaneity: Sound-Space as a Conveyor of Meaning, and Theatrical Roots in Luigi Nono's Early Spatial Practice," Journal of the Royal Musical Association I 37:I (2013): 7I-106; Johanna Ethnersson Pontara, "Music as Excess: Die Reise and Neo-Baroque Aesthetics in Opera from the I960s," STM-Online I6 (2013), accessed December 30, 20I3, http:// musikforskning.se/stmonline/vol_r6/ethnersson/index.php?menu=3; Johanna Ethnersson Pontara, "Narrative and Performative Modalities in the Swedish Opera-in-the-round Dreaming about Thérèse," STMSJM 96:2 (20I4), accessed December I 2, 20I4, http://musikforskning.se/ stm-sjm/node/I 9 .

4 Cf. Claudia Gorbman, "Auteur Music," in Beyond the Soundtrack: Representing Music in Cinema, ed. Daniel Goldmark et al. (Berkeley and Los Angeles: University of California Press, 2007), I 54-I 58.

5 On Tarkovsky, see Tobias Pontara, "Bach at the Space Station: Hermeneutic Pliability and Multiplying Gaps in Andrei Tarkovsky's Solaris," Music, Sound, and the Moving Image, 8: I (20I4): I-23.

${ }^{6}$ Per F. Broman, "Music, Sound, and Silence in the Films of Ingmar Bergman," in Music, Sound and Filmmakers: Sonic Style in Cinema, ed. James Wierzbicki (New York: Routledge, 201 2), I6, I9. 
Luko has observed how he, through the collage-like structure of autobiographical images and film-clips in the opening scene of Persona (I966), "bypasses all pretense of diegesis and communicates directly with the spectator." 7

In the present article concepts and approaches recently developed in the field of intermediality are drawn upon in order to reveal the intermedial qualities of Bergman's Hour of the Wolf (Stockholm I964-68), as an artefact situated in a specific historical context. ${ }^{8}$ Besides with historical issues, the intermedial analysis intersects with considerations of the film's narrative. Hour of the Wolf is, just like Persona, set to music by art-music composer Lars Johan Werle (I926-200I). The film includes modernist music by Werle and Western art music references. ${ }^{9}$ I will argue that Hour of the Wolf can be seen as an example of what Werner Wolf denominates "formal imitation," implying that the media product is shaped "in such a manner that it acquires a formal resemblance to typical features or structures of another medium or heteromedial work." 'о Lars Elleström's distinction between three dimensions of a media product: the basic, the qualified ("the art form," formed by basic media under certain conditions), and the technical (the material-technological display of basic or qualified media) is adapted. I attempt to show how opera (a qualified medium/art form) is suggested in the underlying structure of the film (a qualified medium/art form) through the way in which the included

7 Alexis Luko, Sonatas, Screams, and Silence: Music and Sound in the Films of Ingmar Bergman (New York: Routledge, 20I 5 ), I 44.

${ }^{8}$ The film had its original release in I967 and was re-released in I968. For more on this see Luko, Sonatas, Screams, and Silence, I 30.

9 The study is based on the second version of the film from I968, and on Werle's score of Hour of the Wolf. On the extensive deviances between Bergman's soundtrack and Werle's score, see Broman, “Music, Sound, and Silence," 25-26.

ro Werner Wolf, “(Inter)mediality and the Study of Literature,” Comparative Literature and Culture I 3:3 (20II): 6, accessed January 8, 201 8, http:// docs.lib.purdue.edu/cgi/viewcontent.cgi? article $=\mathrm{I} 789$ \& context=clcweb. Cf. how Jørgen Bruhn makes use of this concept in The Intermediality of Narrative Literature: Medialities Matter (London: Palgrave Macmillan, 2016), 27. 
basic media music, sound effect, image, and speech are combined and displayed through technical media of film. ${ }^{\text {II }}$

The analysis of the film is also informed by Irina O. Rajewsky's division into two sub-categories of intermediality: "media combination" and "intermedial reference." The category of media combination entails that "two medial forms of articulation" are "present in their own materiality and contribute to the constitution and signification of the entire product in their own specific way." ${ }^{22}$ The category of intermedial reference overlaps with Wolf's concept formal imitation, entailing that a media-product "thematizes, evokes, or imitates elements or structures of another, conventionally distinct medium through the use of its own media-specific means." ${ }^{\text {I3 }}$ Framed by the historical context (the early reception and debated ideas) the intermedial analysis will show how the two media genres film and opera both contribute to the constitution of the film by being "present in their own materiality" (that is through media-specific means), and how specific means of the media genre film are used in ways that "evoke an illusion of" operatic qualities. ${ }^{\mathrm{I}}$

I will pay attention to two formal attributes by which the film imitates opera: a division into set numbers or tableaux, ${ }^{\mathrm{I} 5}$ and an emphasis of a double role of the music: as a means by which to construct the diegesis (the illusion of a fictive world), on the one hand, and as a sound object attracting attention to itself, on the other. I draw on recent discourses in opera studies where the genre

ir Lars Elleström, "The Modalities of Media: A Model for Understanding Intermedial Relations," in Media Borders, Multimodality and Intermediality, ed. Lars Elleström (Basingstoke: Palgrave Macmillan, 2010), 26. See also Bruhn, Intermediality of Narrative Literature, I9-20.

I2 Irina O. Rajewsky, "Intermediality, Intertextuality, and Remediation: A Literary Perspective on Intermediality," Intermédialités 6 (2005): 52.

I3 Rajewsky, "Intermediality, Intertextuality, and Remediation," 53.

${ }^{14}$ Rajewsky, "Intermediality, Intertextuality, and Remediation," 57. On the importance of framing intermedial analysis by the historical context, see Rajewsky, "Intermediality, Intertextuality, and Remediation," 50.

is For how film may refer to opera in this way, see Marcia Citron, When Opera Meets Film, 20. 
as a whole has been seen as characterized by this double role of the music both ideologically and structurally. ${ }^{\mathrm{I}}$

Coming to the creation of illusion versus distance through the interaction between visual, verbal, and aural media recent research on the theatrical modes of film and opera is taken into consideration. Broadly speaking, it is a distinction between two ways of creating an audio-visual space: the theatrical (entertaining, spectacular, and rhetorical), implying that the labour behind the way in which the basic media is combined is exposed for the audience, and the cinematic (narrative and affective), implying that the combination of basic media by technical media has the effect of creating illusion and may contribute to absorption. ${ }^{17}$ In her investigation of the dialectical relationship between film and theatre in Bergman's production, Maaret Koskinen has shown how Bergman makes use of the image in a way that enhances oscillation between a cinematic mode of creating affect in the frame of the narrative and a theatrical mode of creating spectacular entertainment, in accordance with film theorist Tom Gunning's concept of "cinema of attractions." ${ }^{8} 8$ Gunning's concept attracts attention to how media can enhance the film viewer's awareness and arouse curiosity. ${ }^{19}$ According to Koskinen, through the close-ups of faces in Persona, for example, diegetic absorption (through transparent narration) is challenged by exhibitionistic confrontation (an

${ }^{16}$ Cf. Christopher Morris, “'Too much Music': The Media of Opera,” in The Cambridge Companion to Opera Studies, ed. Nicholas Till (Cambridge: Cambridge University Press, 2012), 95-I 6.

${ }^{17}$ Cf. Maaret Koskinen, Ingmar Bergman: "Allting föreställer, ingenting är”: Filmen och teatern - en tvärestetisk studie (Nora: Nya Doxa, 200I), I I4-I I 5; Nicholas Ridout, "Opera and the Technologies of Theatrical Production," The Cambridge Companion to Opera Studies, ed. Nicholas Till (Cambridge: Cambridge University Press, 20I2), I67; Robynn Stilwell, "Audio-visual Space in an Era of Technological Convergence," The Oxford Handbook of New Audiovisual Aesthetics, ed. John Richardson et al. (New York: Oxford University Press, 2013), 8.

I8 Koskinen, Ingmar Bergman, I I 5-I 7 .

19 Tom Gunning, "The Cinema of Attractions: Early Film, its Spectator and the Avant-Garde," Wide Angle 8:3/4 (I986): 63-70. 
exposition of performance) in a way that reveals an awareness of the film viewer. ${ }^{20}$

Koskinen argues that this dialectics between cinematic and theatrical modes is important also in Bergman's production of the I960s, consisting of films (for example Persona and Hour of the Wolf) previously being seen as permeated by a cinematic mode. ${ }^{2 \mathrm{I}}$ As to aural media she pays attention to Bergman's use of extended concrete sounds as a means by which to "arouse" the spectator's curiosity. ${ }^{22}$ Gunning's concept, however, is highly useful also for analyzing the roles played by music in relation to sound effects and images. ${ }^{23}$ Moreover, Bergman's experience as opera director and his interest in this media genre are factors that make it interesting to take the audio-visual space as a whole into consideration when analyzing the film.

In his autobiographical book Images (Bilder, I990) Bergman described how he had been fascinated with opera, and more specifically with Mozart's The Magic Flute since childhood. At twelve years old, he attended a performance of this opera at the Royal Opera in Stockholm, and thereafter he wanted to set it at his puppet theatre; however, he did not have the right equipment for the project. ${ }^{24}$ Although interested in staging The Magic Flute as employed at Malmö City Theatre, he got the opportunity first in I974 with a TV production celebrating the fiftieth anniversary of Swedish National Radio and Television. ${ }^{25}$ Already in I96I, however, Bergman had a successful opera production with Igor Stravinsky's The Rake's Progress at the Royal Opera in Stockholm. ${ }^{26}$ The production was revived at the Montreal's

${ }^{20}$ Koskinen, Ingmar Bergman, I I 4-I I 5 .

${ }_{21}$ Koskinen, Ingmar Bergman, 49-50.

22 Cf. Koskinen, Ingmar Bergman, I 50.

${ }^{23}$ Cf. Martha Feldman, Opera and Sovereignty: Transforming Myths in Eighteenth-Century Italy (Chicago: University of Chicago Press, 2007), 95.

${ }_{24}$ Ingmar Bergman, Bilder (Stockholm: Norstedt, I990), 307.

25 Luko, Sonatas, Screams, and Silence, I 4.

${ }^{26}$ Luko lists the operettas and operas that Bergman directed over his lifetime: Bertolt Brecht and Kurt Weill's The Threepenny Opera (I950), Franz Lehár's The Merry Widow (I954), Andreas Randel's The Inhabitants of Värmland (I958), Igor Stravinsky's The Rake's Progress (I96I, I967), Mozart's The Magic Flute (I974), and Daniel Börtz's The Bacchantes 
World's Fair in 1967, and Bergman had plans on directing the same opera at the Hamburg Opera. ${ }^{27}$ Bergman was also as film director influenced by opera and music; at various occasions he compared the film medium to the medium of music, and he described some of his films in relation to operas. ${ }^{28}$ Recently, it has been conveyed how this influence was manifested both structurally and aesthetically in his production. ${ }^{29}$

\section{Hour of the Wolf: Synopsis and Key Scenes}

Hour of the Wolf has attracted attention among scholars for its mixture of realities and ambiguity of point of view, an ambiguity created by alternations between various narrative levels (for example the film producer Bergman, Alma, and Johan)..$^{\circ}$ It has been shown how the music also contributes to this ambiguity. ${ }^{3 \mathrm{I}}$ With the re-release of the film in 1968 , the film was interpreted as a horror movie by critics in Swedish daily journals, and the film was praised for its visual and sonic qualities, above all. ${ }^{22}$

(I99I) in Sonatas, Screams, and Silence, 9. See also Broman, "Music, Sounds, and Silence," I 8-19; Luko, Sonatas, Screams, and Silence, 8-19.

27 These plans were cancelled when Bergman became ill in the spring of I 965. Cf. Luko, Sonatas, Screams, and Silence, I 2-I 5.

${ }^{28}$ Cf. Michael Bird, "Music as Spiritual Metaphor in the Cinema of Ingmar Bergman," Kinema: A Journal for Film and Audiovisual Media (Spring I996), accessed January 4, 2017, http://www.kinema.uwaterloo. ca/article.php? id=3 I 5 \& feature.

29 Cf. Luko, Sonatas, Screams, and Silence, xxiii, 45-70.

$3 \circ$ Cf. Luko, Sonatas, Screams, and Silence, I5 I; Mark B. Sandberg, "Rewriting God's Plot: Ingmar Bergman and Feminine Narrative," Scandinavian Studies 63:I (I99I): I-29.

${ }^{31}$ Luko has shown how in Hour of the Wolf, just like in Persona, Werle's music is used where "fantasy blends with reality," in Sonatas, Screams, and Silence, $\mathrm{I} 34$.

32 Jurgen Schildt, "Demoner i konstnärshuset," review of Hour of the Wolf, by Ingmar Bergman, Aftonbladet, February 20, I968; Lasse Bergström, "Vargtimmen' Skön och rik," review of Hour of the Wolf, by Ingmar Bergman, Expressen, February 20, I968; Mauritz Edström, “'Vargtimmen' Mörkerrädsla för livet," review of Hour of the Wolf, by Ingmar Bergman, Dagens Nyheter, February 20, I968; Carl Henrik Svenstedt, "Kontaktsvårigheter," review of Hour of the Wolf, by Ingmar Bergman, Svenska Dagbladet, February 20, I968; "För och emot 
Critic Karl Henrik Svenstedt described in Svenska Dagbladet on February 20, 1968, how the dimension of the images and the (sound) effects were "ear splitting." The film narrates the story of the painter Johan Borg and his wife, Alma, during a period of time when they are settled on a desolate island. Alma initially narrates about the disappearance of Johan and of her reading of his diary. She recalls what happened after their arrival to the island, and these events are visualized for the film viewer. The couple discover that the desolated island is inhabited and the inhabitants get in touch with Alma, first directly (an old lady), then indirectly through Johan's diary, which she reads (Veronica Vogler and Therapist Heerbrand). One of the inhabitants is Johan's former lover Veronica Vogler, who Alma encounters indirectly by way of reading about a love meeting between her and Johan in the diary (visualized in the film). A key scene of the first part of the film is the performance of a puppet show during a dinner party in the castle of baron von Merken, where Johan and Alma are guests, together with the inhabitants of the island. During the party, the atmosphere increasingly becomes oppressive with a culmination at the puppet show, where Johan appears to be the target of the performance.

In the second part of the film, the inhabitants' influence on the lives of Johan and Alma intensifies. A key scene is a flashback of Johan, which has a dreamlike character and narrates how he, while fishing on the rocks, encounters a young boy and finally kills him. An important sequence is also when Johan, having fired a pistol shot on Alma, returns to the castle in search for Veronica Vogler and becomes the laughing-stock of the inhabitants. The film ends as it begins, with Alma as narrator of Johan's destiny. Her final glimpse of Johan is shown in a flashback, which, just like the earlier scene of Johan and the boy on the rocks, has a dreamlike character. Eventually it is suggested that the inhabitants are demons of Johan's disturbed interior, which also Alma has begun to see. ${ }^{33}$

'Vargtimmen,'” Svenska Dagbladet, February 2 I, I968; "Vargtimmen," Expressen, March I 5, I968.

33 Cf. Luko, Sonatas, Screams and Silence, I 5 I. 


\section{Formal Imitation of Opera through the Combination of Speech and Sound Effects}

Considering the storyline and the characterization of certain characters Hour of the Wolf alludes to The Magic Flute. Johan's search for Veronica Vogler is a parallel to Tamino's search for Pamina, ${ }^{34}$ and the character Archivist Lindhorst, in the film named "the bird man," is based on the character Papageno. ${ }^{35}$ The title of the film is repeated in the middle of the film, the words in white against a dark backdrop, a device that, just like the drop curtain of a theatre (and opera) performance, emphasizes a division into two parts and has a distancing effect. ${ }^{36}$ Each part of the film is verbally configured as an alternation between monologues, dialogues, and ensembles, in a set numberlike structure. Rather than interacting verbally with each other, the characters (above all the inhabitants) formulate themselves in long one-way monologues resembling verbal arias.

In the first part of the film inhabitants of the island are introduced in the narrative presenting themselves in one verbal monologue each. The part culminates at the dinner party in baron von Merken's castle, where Alma and Johan are dinner guests. The scene is introduced as a chaotic sonic space of various speeches of foregrounded voices. Gradually, however, individual speeches come to the fore, whereas the web of voices forms a sonic background. The intertwined speeches come to function as an accompaniment to individual monologues. This texture is occasionally broken by outbursts of unison laughter. By filmic technical media (such as sonic extension, foregrounding, and backgrounding) the voices are related to each other in textures evoking the illusion of an ensemble number in the qualified medium opera. It is an interchange between monologues with accompaniment, counterpoint,

${ }^{4}$ Cf. Broman, "Music, Sound, and Silence," 24.

35 Cf. Martin Nedbal, "Live Marionettes and Divas on the Strings: Die Zauberflöte's Interactions with Puppet Theatre," The Opera Quarterly 28:I-2 (2012): 29; Luko, Sonatas, Screams and Silence, I33.

${ }^{6} 6$ On the "Brechtian alienation effect" of this device see Luko, Sonatas, Screams, and Silence, I45. 
and unison texture. ${ }^{37}$ This aural and verbal construction make the scene appear as a separate number.

The tableau-like structure of the film is also created through a combination of speech with sound effects that are manipulated by cinematic technical media. The vocal monologues of the inhabitants in the first part of the film are accompanied by extended natural sounds. Each monologue is surrounded by a certain soundscape, and these environmental sounds may occasionally dominate the sonic space whereas the voices are muted. The monologue of Veronica Vogler is surrounded by the sound of waves, whereas the monologue of Therapist Heerbrand is surrounded by the sound of a strong wind. The combination of sonic and vocal performance is especially remarkable in the monologue of the old lady, the first inhabitant introduced in the film, who appears before Alma directly. Her appearance is preceded by an extension of the environmental sounds, a strong wind, bird calls, and waves, and when she is discovered by Alma, the woman performs a one-way monologue against this soundscape. There is an interchange between vocal and sonic phrases, and at the second part of the monologue, the natural sounds occasionally substitute for the voice and dominate the sonic space entirely. ${ }^{38}$ The soundscape continues after the end of the monologue, and ties the event together as a sonic unit. However, as Alma enters the house it is abruptly broken.

Framing the monologue by foregrounded sound effects, and alternating between speech and sound effects in the audio-visual space, Bergman uses technical media of film in a way that structures the monologue as a set piece. Just like in an opera aria individual media (the speech and the sound effects) occasionally attract the attention of the film spectator, appearing as qualified media (individual aesthetic entities) rather than basic media (the entities of

37 Luko characterizes the conversation as "a cacophony resulting from a confluence of one-way monologues," and the "beakdown of verbal conversation," in Sonatas, Screams, and Silence, I 33.

${ }^{8}$ Cf. Luko, who interprets this moment as an "aural out-of-focus moment," in Sonatas, Screams, and Silence, I32. 
qualified media). This is achieved through the use of technical media of film, such as manipulations of tape of sound effects and tape of speech.

\section{Formal Imitation of Opera through the Use of Opera}

Although music is used sparingly in the film, it is an important structural device in the scenes where it occurs. Of certain importance is the introduction of an actual opera number towards the end of the first part of the film: Tamino's "O ewige Nacht" from The Magic Flute. This was one of the moments mentioned by Corliss and Hoops in their review of the film, and it motivated their characterization "frankly operatic." 39 The scene also attracted attention among the critics in Swedish daily papers..$^{\circ}$ In The Magic Flute this aria-like number is a vocal gesture of resignation performed by Tamino in his search for Pamina, and a choir of priests responds to his expression. ${ }^{4 \mathrm{I}}$ In his autobiographical book Laterna Magica (I987), Bergman stated that this was the scene affecting him most in the opera. ${ }^{42}$ The Magic Flute number is featured during the puppet show performed in the scene following the dinner conversations, mentioned earlier, at the dinner party in the castle.

The dinner guests are gathered in front of a puppet stage and Archivist Lindhorst acts as puppeteer, standing behind the stage. On his command the instrumental prelude of Tamino's " $O$ ewige Nacht" starts. The descending musical movement is synchronized with a descending movement of the camera, followed by an ascending movement as the curtain of the theatre raises. As the vocal part begins, a puppet appears on stage; however, it is a puppet

\footnotetext{
39 Corliss and Hoops, "Hour of the Wolf," 38.

$4 \circ$ Schildt, "Demoner i konstnärshuset”; Bergström, “Vargtimmen' Skön och rik”; Edström, “Vargtimmen’ Mörkerrädsla för livet.”

${ }^{4}$ B Broman draws an existential parallel between Tamino's words and Bergman's intentions in "Music, Sound, and Silence," 25. Nedbal, in turn, argues that Bergman makes use of puppets in order to distance the film's audience from the opera's conventional meaning in "Live Marionettes and Divas on the Strings," 27.

${ }^{42}$ Ingmar Bergman, Laterna Magica (Stockholm: Norstedt, I987), 25 I.
} 
of flesh and blood, a miniaturized human puppet in a twisted pose with raised hands. ${ }^{43}$ The moment is built up of a mixture of pre-recorded performance (the technical media of film is taken into consideration), a representation of a fictive reality (a part of the qualified medium film), and a representation of a dreamlike twist of this reality through the image of the performer (a manipulation through technical media). The use of an actual human being on stage suggests the performative mode of the qualified media opera and theatre. The illusion of an opera performance is also created through the use of technical media of film; when the music starts, the action "freezes" as Bergman lets the camera move around the audience with close-ups of experiencing faces. ${ }^{44}$ At the same time, the live puppet representation in small proportion is a clearly filmic device.

The scene reveals how certain intermedial qualities are at play coming to how modes of the qualified media film and opera are combined. In accordance with the intermedial quality Rajewsky has labelled "media combination" it appears at first glance as two medial forms of articulation are "present in their own materiality and contribute to the constitution and signification of the entire product in their own specific way." 45 Opera is present musically and verbally through a specific number played in its entirety. Borrowing the words of Marcia Citron, the medium "is present in an obvious way that makes it recognizable.” ${ }^{46}$ Bergman, however, also calls attention to the musical number as sound object through the camera work (freezing the action through close-ups of faces of attentive spectators/listeners). ${ }^{47} \mathrm{~A}$ closer analysis of the film shows

43 Cf. Broman, "Music, Sound, and Silence," 24.

44 On how the music may freeze the narrative, see Nicholas Cook, Analysing Musical Multimedia (Oxford and New York: Oxford University Press, I998), 227.

45 Rajewsky, “Intermediality, Intertextuality, and Remediation,” 52.

${ }^{46}$ Citron, When Opera Meets Film, 246.

47 Broman has paid attention to how the section emphasises music's ability to immerse its audience, humans as well as demons in "Music, Sound, and Silence," 25. See also Luko's consideration of Bergman's way of "watching the listener," in Sonatas, Screams, and Silence, 3 I-33. 
that various modes are emphasized in the scene through a process of change in the configuration of the audio-visual space.

As to the configuration of the audio-visual space in film, film music scholar Robynn Stilwell has distinguished between a theatrical and a filmic mode. Each mode is based on audio-visual conventions, including for example the placement of music, "the way sound/speech are represented through sound design, camera, editing, lighting, performance, style." ${ }^{8}$ She shows how the music-image relationship can differ coming to shape and texture and thereby may create theatrical versus cinematic experiences. ${ }^{49}$

The way in which the music is used initially in the scene conveys a theatrical mode. As the Magic Flute excerpt is introduced, the music is diegetic through its connection to the puppet show; it is experienced as music by the fictive characters. Also the sound quality (created by technical media) contributes to this position as the music is muted, which indicates that it emanates from a recording. It is a re-mediation of opera that takes the technological consequences of the production and distribution of the music into consideration in the representation, which means that a theatrical mode is at play. The technological implications of the mediation are revealed for the film viewer. ${ }^{\circ}$

However, successively the mode of using the basic media becomes cinematic, as the music comes to be subordinated to the narrative role of creating illusion. The camera moves around the audience with close-ups of faces of listening persons at the same time as the sound quality changes. The sound becomes clearer and the volume is elevated. The status of the music appears to transform from diegetic to non-diegetic. The production of music is in a cinematic mode subordinated to the narrative and integrated in the cinematic apparatus of production. As the camera moves around the spectators/listeners with close-ups of faces the music gets a foreground position with a build-up at Tamino's culminating outbreak of despair.

$4^{8}$ Stilwell, "Audio-visual Space in an Era of Technological Convergence," 2.

49 Stilwell, "Audio-visual Space in an Era of Technological Convergence," I.

5० Cf. Stilwell, "Audio-visual Space in an Era of Technological Convergence," I-2; Ridout, "Opera and the Technologies of Theatrical Production," $\mathrm{I} 67$. 
With this vocal climax, the mode becomes operatic, as the music attracts attention to itself as a sound object. The music is foregrounded in the audio-visual space to such an extent that it attracts the attention also of the real audience (the film viewer), and it is its status as qualified medium (a work of art) that is emphasized as much as its status as a means of creating a fictive world (how it works as a basic medium). The way in which Bergman lets the footage follow the musical development with hesitating movements that reinforce the vocal climax and the following decrescendo contributes to this impression. He lets the music guide the filmic apparatus of the production. In this way a technical medium of opera, the vocal climax, is reinforced. This is an example of what Citron labels "operaticness," implying that opera is "celebrated" through a specific trait. ${ }^{51}$ Accordingly, the technical media of film are used in a way that reinforces a characteristic trait of opera as a media genre..$^{52}$

\section{Formal Imitation of Opera through the Combination of Music, Sound Effects, and Images}

In the second part of the film, the music plays an important structural role in combination with sound effects and images. The music having this role is the modernist music by Werle. This part of the film includes two mute flashbacks, transcending from a dialogue, and a monologue respectively, each connected to the characters Johan and Alma. The dialogue and monologue are set in a theatrical mode visually, verbally, and sonically. The way in which the characters appear in front of the camera, and express themselves surrounded by environmental sounds is realistic and the means of production is revealed to the film viewer. ${ }^{53}$ The two flashbacks, on the contrary, have an abstract and dreamlike character. Together with the Mozart excerpt, these two scenes set to

${ }^{51}$ Citron, When Opera Meets Film, 246.

52 Cf. Rajewsky, "Intermediality, Intertextuality, and Remediation," 57.

53 Cf. Koskinen, Ingmar Bergman, II4-II7; Ridout, "Opera and the Technologies of Theatrical Production," I67; Stilwell, "Audio-visual Space in an Era of Technological Convergence," 8. 
music by Werle, were the moments above all attracting attention among the Swedish critics of the film. ${ }^{54}$

The two scenes open up new audio-visual modes that differ from the theatrical mode of the framing monologue and dialogue, respectively, and gives them the character of what Stilwell terms "cinematic bubbles." 55 However, the effect of them is spectacular rather than affective cinematic through Werle's obtrusive modernistic score upon which Bergman superimposes sound effects and through oscillations between gestural synchronicity and counterpoint.

The flashback of Johan is mute and shows Johan encountering a boy on the rocks above the sea. The audio-visual configuration of the scene makes it deviate from the film at large. The footage is overexposed, and the sonic world is made up of modernistic sound constellations and of silence. Also the structure of the scene as a whole contributes to the creation of a self-sufficient entity with an exposition, a build-up to a climax, and a recapitulation. Initially, Johan and the boy are seen from a distance; Johan is fishing and the boy observes him. Eventually, the boy runs to look at Johan's things, which are put on the ground nearby. The music has a sighing character with sounds that are cut in separately and are suspended. As Johan and the boy suddenly make eye contact, a dissonant chord in low register creates a tense character. At this moment there is a build-up of sonic intensification, which culminates in a chaotic sonic world as the boy is shown in close-up from behind standing right behind Johan. A moment of relaxation is followed by the return of the initial sonic "sighing" character as Johan and the boy leaves their positions on the rocks. Thereafter a second section of intensification leads to a climax where Johan confronts the boy. The climax consists of a combination of drastic images and sounds oscillating between reinforcing and contradicting each other coming to movement and content.

54 Cf. Svenstedt, “Kontaktsvårigheter”; Edström, “'Vargtimmen’ Mörkerrädsla för livet."

55 Stilwell, "Audio-visual Space in the Era of Technological Convergence," 6,8 . 
Broman has paid attention to how expectations are contradicted through this combination of music and synthetic sounds with the forceful images:

Musically the scene is remarkable, with a combination of conventional Hollywood suspense clichés, mickey-mousing, and stingers. The insertion of the boy's screams, in a scene devoid of natural sounds, is very effective and adds a layer of almost comic absurdity. Importantly, the music challenges the images by renouncing and contradicting them. ${ }^{6}$

The images show actions appearing to demand realistic sounds: the conniption of Johan shouting furiously at the boy, the boy screaming and biting Johan, Johan furiously hitting the boy and throwing him into the water. However, the scene is mute, and synthetic sound effects substitute for the natural sounds. Through synthetic sound effects and abrupt silence the actions are contradicted and exaggerated. At some moments the use of rhythmic and dissonant intensification and of silence is foregrounded to the extent of intruding upon the film viewer. In these moments the footage appears to be "enveloped by" the sonic and the mute world, respectively. ${ }^{57}$ As Johan has thrown the body of the boy into the water the musical character initiating the scene returns, the musical gestures following the movements of the image; the body of the boy rising to the surface of the water.

The scene can be seen as a realization of Rajewsky's intermedial quality "intermedial reference," as the means of film (its technical media) is used in a way that create an audio-visual structure that evokes an effect of the qualified medium opera. ${ }^{58}$ The scene is audio-visually configured as a self-contained number that deviates from the audio-visual space of the film at large. Moreover, individual media are foregrounded as visual and sonic objects (that is as qualified media rather than as basic media) through the synthetic quality and through unexpectedness of the action-sound combination with oscillations between gestural synchronicity and

${ }^{56}$ Broman, "Music, Sound, and Silence," 26.

57 Cf. Stilwell, "Audio-visual Space in the Era of Technological Convergence," 23.

${ }^{8}$ Rajewsky, “Intermediality, Intertextuality, and Remediation," 57. 
counterpoint at the climax. It is a modernist audio-visual space where the media attract attention to themselves as visual and sonic objects. In this way they also evoke an illusion of the double role of media in an opera aria. As to the music its role as sonic attraction (that is as qualified medium) is emphasized at the expense of its role as diegetic construction (that is as a basic medium of the qualified media of opera or film) through the way in which it is combined with sound effects.

Bergman also lets Werle's modernistic music substitute for vocal expression at the climax of the second part of the film where Johan becomes the laughing-stock of the inhabitants. Johan's monologue is suddenly muted and substituted by a sound that successively expands at the same time as the camera zooms in on Johan's face to the extent of blurriness. The image dissolves into the image of the boy's body floating in the water from the scene of Johan and the boy on the rocks. Just like in this other scene, the music and the images are reinforced as visual and sonic objects (making them appear as qualified media as much as of basic media) through the substitution of the vocal expression for the extended dissonant sound constellations in combination with the camera work.

The film ends as it starts, with a monologue of Alma; looking into the camera, she gives details about Johan's disappearance and of his diary. Eventually, her narration turns into a flashback (a visualization of the narrated events) breaking with the realistic mode of the scene through an overexposed footage in combination with extended natural sounds. It is shown how Alma searches for Johan in the forest, finds him, and they embrace with eyes closed. The camera zooms in on Alma's face and there is a cut with a doubling of the image. Alma appears to wake up, Johan has disappeared and instead she is confronted with one of the inhabitants, baron von Merken. As she discovers Johan the sequence dissolves into a montage of close-ups of Johan being beaten and injured and of Alma screaming. The images are combined with constellations of synthetic sounds in an audio-visual montage that oscillates between synchronization and counterpoint regarding the audio-visual movements.

In Analysing Musical Multimedia Nicholas Cook has shown how the music can be foregrounded in a narrative through 
structural devices, such as the da capo form of an aria, and in this way contribute to an experience of "formal intrusion." 59 At the end of Alma's flashback in Hour of the Wolf, the combination of montage technique, technologically manipulated images and sounds, and alternation between gestural synchronization and counterpoint (that is, through technical media) contribute to such formal quality. ${ }^{60}$ The excessive sonic world of the scene of Johan and the boy on the rocks is re-established (this sonic world also recurs in the scene where Johan fires a pistol-shot on Alma) ${ }^{6 r}$ and is foregrounded in relation to the images. A steady editing of close-ups is combined with manipulated, tape-recorded sound constellations. An initial stinger consisting of a foregrounded stylized sound effect is synchronized with the cut to a close-up of the mute scream of Alma. A forward-driving, metallic sound effect, overlaps the cut to an image where Johan is beaten and falls, mickey mousing his gesture. Thereafter sounds are cut in separately and are suspended (it is a re-establishment of the dissonant sonic world that initiates and appears at the end of the scene with Johan and the boy on the rocks) over cuts between close-ups.

The oscillation between synchronicity and counterpoint coming to visual and sonic movements creates the impression of two abstract montages being at play at the same time, a visual and a sonic. Together with the cutting rhythm and gestural movements the synthetic sonic and visual quality highlights the opacity of visual and sonic media and contributes to the stylized effect. The cinematic visual working through close-ups in steady editing is foregrounded and juxtaposed with foregrounded sound constellations in a way that makes the scene appear as a spectacular tableau. ${ }^{62}$ Just like at the climax of the scene of Johan and the boy on the rocks the narrative is subordinated to the abstract beauty of the audio-visual space in a way that creates an illusion of an aria in the qualified medium opera. ${ }^{63}$

59 Cook, Analysing Musical Multimedia, 220.

60 Cook, Analysing Musical Multimedia, 226.

${ }^{61}$ Cf. Luko, Sonatas, Screams, and Silence, I57-I6I; Broman, "Music, Sound, and Silence," 26.

${ }^{62}$ Cf. Citron, When Opera Meets Film, 26.

${ }_{63}$ Cf. Rajewsky, "Intermediality, Intertextuality, and Remediation," 54-55. 


\section{Historical Contextualization: Medial Mixedness versus Medial Purity}

The intermedial dimension of formal imitation being highlighted in Hour of the Wolf, with emphasis of the role played by the music, can be framed by the historical discussion of mixed versus pure medialities. ${ }^{64}$ The film should be seen in the light of the debates around the relationship between music and other media and between various media genres among the Swedish avant-garde during the period $1940-50$, discussing in what sense the arts could be seen as separated by distinctive properties or exchangeable coming to expressive means and aesthetic conventions. ${ }^{65} \mathrm{~A}$ key figure in these debates was art-music composer Karl-Birger Blomdahl, who proclaimed that music should participate in film and other media genres in a manner appropriate to the medium and not be subordinated to visual and verbal media. ${ }^{66} \mathrm{He}$ meant that the aesthetic value of film, just like of opera and ballet, was enhanced if the arts included were joined on equal conditions, without any art dominating another. ${ }^{67}$ Moreover, he posited that the film music composer should be free to avail himself of any sound and also of silence. ${ }^{68}$

It has been shown how Blomdahl's ideas about how music should be related to sound and image in film coincided with similar ideas of Bergman, who in turn was influenced by the aural language of the plays by August Strindberg. ${ }^{69}$ An important issue of Blomdahl's and Bergman's ideas was the relationship between music and sound effect. Luko has pointed to how the distinction between music and sound effect is blurred in Bergman's film Sawdust and Tinsel (I953), in the scene where the clown Frost

${ }^{64}$ Cf. Bruhn, Intermediality of Narrative Literature, I2. See also Morris, “'Too much Music,'” 95-97.

${ }^{65}$ Cf. Christina Tobeck, Karl-Birger Blomdahl: En Musikbiografi med inriktning på förhållandet mellan ord och ton $i$ hans tidiga produktion, vol. I-II, (PhD diss., University of Gothenburg, 2002), 355, 359-360, 385-386.

${ }^{66}$ Cf. Tobeck, Karl-Birger Blomdahl, I: 409, II: 75-76.

${ }_{67}$ Tobeck, Karl-Birger Blomdahl, II: 75-76.

68 Luko, Sonatas, Screams, and Silence, 50.

69 Luko, Sonatas, Screams, and Silence, 50, I8I-I95. 
finds his wife, Alma, as she is bathing naked with soldiers. Here, Blomdahl's soundtrack not only has the character of sound effect through dissonant and rhythmic irregular ostinatos where individual pitches are emphasized and through a setting dominated by wind instruments and percussions, but Bergman also superimposes sounds of cannon firing on this music. Moreover, the aural media music, sound effect, and later in the sequence silence, are foregrounded in the audio-visual space and contribute, together with an over-exposed footage, to an abstract character that makes the scene unique in the film. ${ }^{70}$

The two scenes in Hour of the Wolf, scored by Werle, have affinity audio-visually with this scene in Sawdust and Tinsel. ${ }^{\text {I }}$ The view of music's position in relation to other media, presented by Blomdahl, appears to have been of importance also for Werle during this period of time. In an interview published in a Swedish daily journal in the late I960s Werle posited that his ambition was to create contradiction between music and other media rather than interaction. ${ }^{72}$ Bergman's Persona (I966) and the ballet Zodiak (I966) are mentioned as examples of how counterpoint is created between Werle's music and images and bodily movements respectively. ${ }^{73}$

Besides in media mixedness versus media specificity, the media production of the Swedish I960s, conveys an interest in media genre mixedness versus media genre specificity. In, for example, the music theatrical productions of Werle and director and librettist Lars Runsten: Dreaming about Thérèse and The Journey, the media genres opera, TV, and film intersect. ${ }^{74}$ The media genres are

${ }^{70}$ Luko, Sonatas, Screams, and Silence, 5 I-59, 67-68; cf. Broman, "Music, Sound, and Silence," 26; Koskinen, Ingmar Bergman, I 49.

${ }^{71}$ Cf. Broman, "Music, Sound, and Silence," 26.

${ }^{22}$ "En socialt anpassad rebell i folkhemmets lugna trygghet," Svenska Dagbladet, February I2, I967.

73 “En socialt anpassad rebell." The image-music-sound relationship is also interesting in the scenes having music by Werle in Alf Sjöberg's film The Island (I966). Here, forceful images are combined with a chaotic sonic world of free jazz where the distinction between music and sound effect is dissolved.

${ }^{74}$ Cf. Ethnersson Pontara, "Music as Excess," and "Narrative and Performative Modalities." 
mixed, however, in ways enhancing their specific traits. Bergman's film production of the I960s can be seen as belonging to this category of productions too, not only visually, but also through the way in which music is used in relation to sound effects and images. ${ }^{75}$ Accordingly, the structural imitation of another media genre in Hour of the Wolf conveys a modernist approach where individual media are distinguished in the moment of combination, an approach that also was used on the level of media genre, where media genres were distinguished within one and the same media product.

\section{Final Reflections}

With point of departure in a specific historical context this article has highlighted how certain intermedial qualities can be revealed by the film Hour of the Wolf's connection to opera. ${ }^{76}$ It has been shown how the film imitates opera through a division into set numbers and through the double role of music as subordinated to a narrative in order to create illusion (that is, as a basic medium), on the one hand, and as attracting attention to itself as a sound object and arousing the film viewer's curiosity, on the other (that is, as a qualified medium). The disclosement of the intermedial quality of formal imitation highlights how the film was integrated in discourses on the relationship between media in the I960s, not only coming to visual and verbal media, but also regarding the music. In this modernistic context, media objects were not only characterized by media specificity as to individual media, but also coming to how they structurally were indebted to other media genres.

The way in which Bergman foregrounds music as a sound object in the film Hour of the Wolf can be compared to the way in which he foregrounds the spectacular effect of images in the film, which has been shown by Koskinen. The investigation of the scenes in Hour of the Wolf suggests that sound and music are as

75 Cf. Koskinen, who, however, posits that the modes of theatre and film are fused, in Ingmar Bergman, I 6.

${ }^{76}$ Cf. Bruhn, Intermediality of Narrative Literature, 24. 
important as the image for a challenge of "diegetic absorption" through "exhibitionistic confrontation." 77 To this challenge contributes not only the use of an actual opera number in the film, but also the way in which Werles music is combined with sound effects and images.

The two scenes of Johan's and Alma's flashbacks in the second part of the film appear as autonomous montages freezing the narrative, as images, sounds, and music have the effect of opacity instead of transparency. Musical opacity is displayed through sound constellations generated by new technology and through oscillations between synchronicity and counterpoint coming to the relationship between musical and visual movements and expressions. Through these devices, these media appear as aesthetic entities (rather than basic media subordinated to the narrative). The music thereby contributes to the dialectical relationship between diegetic absorption and attracting entertainment that is an important experience of much art film,$^{78}$ which points to opera. The way in which sounds, music, and images are foregrounded makes the effect of spectacular excess enhanced at the expense of the affective absorbing. Borrowing the word of Koskinen, the scenes are experienced as audio-visual shocks. ${ }^{79}$

\section{References}

\section{Books and Articles}

Bird, Michael. "Music as Spiritual Metaphor in the Cinema of Ingmar Bergman.” Kinema: A Journal for Film and Audiovisual Media (Spring I996). Accessed January 4, 20I7. http://www.kinema.uwaterloo.ca/ article.php? id=3 5 \&feature

Bergman, Ingmar. Bilder. Stockholm: Norstedt, I990.

Bergman, Ingmar. Laterna Magica. Stockholm: Norstedt, I987.

77 Koskinen, Ingmar Bergman, I I 4-I I 5 .

${ }^{78}$ Cf. Koskinen, Ingmar Bergman, I I 7; Gunning, “The Cinema of Attractions," $63-70$.

79 Koskinen, Ingmar Bergman, I I 5-I I 7 . 
Boyd, Harriet. "Remaking Reality: Echoes, Noise and Modernist Realism in Luigi Nono's Intolleranza I960." Cambridge Opera Journal 24:2 (2012): I77-200.

Broman, Per F. "Music, Sound, and Silence in the Films of Ingmar Bergman.” In Music, Sound and Filmmakers: Sonic Style in Cinema, edited by James Wierzbicki, I6-3I. New York: Routledge, 20 I 2.

Bruhn, Jørgen. The Intermediality of Narrative Literature: Medialities Matter. London: Palgrave Macmillan, 20I6.

Citron, Marcia. When Opera Meets Film. Cambridge: Cambridge University Press, 20 Iо.

Cook, Nicholas. Analysing Musical Multimedia. Oxford and New York: Oxford University Press, I998.

Corliss, Richard, and Jonathan Hoops. "Hour of the Wolf," review of Hour of The Wolf, by Ingmar Bergman. Film Quarterly 2 I:4 (I968): 33-40. Accessed October 29, 20I 5. http://www.jstor.org/ stable/I 2 I0600?seq=I\#page_scan_tab_contents.

Elleström,Lars. "The Modalities of Media: A Model for Understanding Intermedial Relations." In Media Borders, Multimodality and Intermediality, edited by Lars Elleström, II-48. Basingstoke: Palgrave Macmillan, 20I0.

Ethnersson Pontara, Johanna. "Music as Excess: Die Reise and NeoBaroque Aesthetics in Opera from the I960s." STM-Online I6 (2013): I-32. Accessed December 30, 20I3. http://musikforskning. se/stmonline/vol_i6/ethnersson/index.php?menu=3.

Ethnersson Pontara, Johanna. "Narrative and Performative Modalities in the Swedish Opera-in-the-round Dreaming about Thérèse." STM-SJM 96:2 (20I4). Accessed December I2, 20 I 4. http://www.musikforskning.se/stm-sjm/node/I9.

Feldman, Martha. Opera and Sovereignty: Transforming Myths in Eighteenth-Century Italy. Chicago: University of Chicago Press, 2007.

Gorbman, Claudia. "Auteur Music." In Beyond the Soundtrack: Representing Music in Cinema, edited by Daniel Goldmark, Lawrence Kramer, and Richard Leppert, I49-I62. Berkeley and Los Angeles: University of California Press, 2007. 
Gorbman, Claudia. "Ears Wide Open: Kubrick's Music.” In Changing Tunes: The Use of Pre-existing Music in Film, edited by Phil Powrie and Robynn Stilwell, 3-I8. Aldershot: Ashgate, 2006.

Gunning, Tom. "The Cinema of Attractions: Early Film, its Spectator and the Avant-Garde." Wide Angle 8:3/4 (I986): 63-70.

Jeongwon, Joe, and Rose Theresa, eds. Between Opera and Cinema. New York: Routledge, 2002.

Koskinen, Maaret. Ingmar Bergman: "Allting föreställer, ingenting är”: Filmen och teatern - en tvärestetisk studie. Nora: Nya Doxa, 2001 .

Luko, Alexis. Sonatas, Screams, and Silence: Music and Sound in the Films of Ingmar Bergman. New York: Routledge, 2015.

Morris, Christopher. “'Too much Music': The Media of Opera.” In The Cambridge Companion to Opera Studies, edited by Nicholas Till, 95-I r6. Cambridge: Cambridge University Press, 20 I 2.

Nedbal, Martin. "Live Marionettes and Divas on the Strings: Die Zauberflöte's Interactions with Puppet Theatre." The Opera Quarterly 28:I-2 (20I2): 20-36.

Pontara, Tobias. "Bach at the Space Station: Hermeneutic Pliability and Multiplying Gaps in Andrei Tarkovsky's Solaris." Music, Sound, and the Moving Image 8:I (20I4): I-23.

Rajewsky, Irina O. "Intermediality, Intertextuality, and Remediation: A Literary Perspective on Intermediality." Intermédialités 6 (2005): $43-64$.

Ridout, Nicholas. "Opera and the Technologies of Theatrical Production." In The Cambridge Companion to Opera Studies, edited by Nicholas Till, I59-I76. Cambridge: Cambridge University Press, $20 \mathrm{I} 2$.

Sandberg, Mark B. "Rewriting God's Plot: Ingmar Bergman and Feminine Narrative." Scandinavian Studies 63:I (I99I): I-29.

Santini, Andrea. "Multiplicity - Fragmentation - Simultaneity: Sound-Space as a Conveyor of Meaning, and Theatrical Roots in Luigi Nono's Early Spatial Practice." Journal of the Royal Musical Association I37:I (20I2): 7 I-IO6. 
Stilwell, Robynn. "Audio-visual Space in an Era of Technological Convergence." In The Oxford Handbook of New Audiovisual Aesthetics, edited by John Richardson, Claudia Gorbman, and Carol Vernallis, I25-I45. New York: Oxford University Press, 2013 .

Tobeck, Christina. Karl-Birger Blomdahl: En Musikbiografi med inriktning $p a ̊$ förhållandet mellan ord och ton $i$ hans tidiga Produktion, vol. I-II. PhD diss. University of Gothenburg, 2002.

Wolf, Werner. "(Inter)mediality and the Study of Literature," Comparative Literature and Culture I3:3 (20II): I-9. Accessed January 8, 20I 8. http://docs.lib.purdue.edu/cgi/viewcontent. cgi article $=\mathrm{I} 789 \&$ context $=$ clcweb.

\section{Reports and Reviews from Daily Papers}

Anonymous ("Ulrika"). "En socialt anpassad rebell i folkhemmets lugna trygghet.” Svenska Dagbladet, February I2, 1967.

Anonymous. "För och emot "Vargtimmen." Svenska Dagbladet, February 21, I968.

Anonymous. "Vargtimmen.” Expressen, March I 5, I968.

Bergström, Lasse. “'Vargtimmen' Skön och rik.” Expressen, February 20, 1968.

Edström, Mauritz. “'Vargtimmen’ Mörkrädslan för livet.” Dagens Nybeter, February 20, I968.

Schildt, Jurgen. “Demoner i Konstnärshuset.” Aftonbladet, February 20, 1968.

Svenstedt, Carl Henrik. "Kontaktsvårigheter." Svenska Dagbladet February 20, I968.

\section{Film and Score}

Bergman, Ingmar. Vargtimmen (Hour of the Wolf), I968.

Werle, Lars Johan. Score for Vargtimmen (Hour of the Wolf), I968. 